\title{
Family Involvement in Ownership, Management, and Firm Performance: Moderating and Direct-Effect Models
}

\author{
Shehabaddin Abdullah A. Al-Dubai ${ }^{1}, \mathrm{Ku}$ Nor Izah Ku Ismail ${ }^{2}$ \& Noor Afza Amran ${ }^{2}$ \\ ${ }^{1}$ Salahaddin Excellence Metal Co., Taiz, Republic of Yemen \\ ${ }^{2}$ College of Business, Universiti Utara Malaysia, Sintok, Kedah, Malaysia \\ Correspondence: Shehabaddin Abdullah A. Al-Dubai, Salahaddin Excellence Metal Co., Taiz, Republic of \\ Yemen. Tel: 60-13-491-0930. E-mail: shihabaddin@yahoo.com
}

\author{
Received: April 26, 2014 Accepted: May 14, 2014 Online Published: June 24, 2014 \\ doi:10.5539/ass.v10n14p193 \\ URL: http://dx.doi.org/10.5539/ass.v10n14p193
}

\begin{abstract}
This study aims to provide an empirical evidence on the moderating effect of family involvement in management (family CEO and founder CEO) on the relationship between family ownership and firm's performance. From a sample of 75 public listed companies (375 firm-year observations) in Saudi Arabia, we use a five-year interval (2007-2011) and two firm performance indicators (market to book value (MBV) and return on assets (ROA)) to test five hypotheses. The hypotheses that there is a direct impact of family ownership and founder CEO on ROA and MBV were supported respectively. The hypothetical moderating impact of family CEO and founder CEO have been partially confirmed with MBV. Overall, the findings highlight the importance of occupying CEO positions in family firms by family members, especially the founders for gaining better performance. However, the results are robust when only family firms are examined separately.
\end{abstract}

Keywords: family business, family ownership, family CEO, founder CEO, firm performance, Saudi Arabia, moderating effect

\section{Introduction}

The current global economic system is saturated with family businesses, the most common type of business in industrialized as well as developing countries (Astrachan \& Shanker, 2003; Zahra \& Sharma, 2004). As a result, the topic of family business takes a special place in academicians and practitioners' writings, as evidenced by the amount of research dedicated to it (e.g., Astrachan \& Shanker, 2003; Rutherford, Kuratko, \& Holt, 2008). On the basis of these activities, family firm performance is considered an important variable in the context of financial and management research (Sacristan-Navarro, Gomez-Anson, \& Cabeza-Garcia, 2011) and commonly known as a distinct and important field of study (Walsh, 2007).

Recently, many gaps in family business research have been reported (Collins \& O'Regan, 2011). Among these gaps is the link between family involvement and its effect on the performance, which is still under debate (Filatotchev, Lien, \& Piesse, 2005). Any current evidence extending knowledge that causes the inconsistent empirical literature is valuable (Sacristan-Navarro et al., 2011), as these inconsistencies have made the link between family involvement in ownership and firm performance more "complex and very probably moderated or mediated by factors..." (Mazzi, 2011, p. 166). Literarily, testing for moderating-effect is called for when contradictory findings surround the relationship between a predictor and criterion, which in turn, opens the question on whether the relationship between the two variables is depending on a third variable ( Dawson, 2013; O’Boyle, Pollack, \& Rutherford, 2012; Baron \& Kenny, 1986).

Researchers urged to provide a rational answer on the question of the moderation effect. O'Boyle et al. (2012), for example, took the initiative of answering such question by conducting a meta-analysis technique to analyse 78 related articles. They postulate a number of hypothetical moderating effects of some conceptual moderators (i.e., firm type, firm size, and culture) and methodological moderators (i.e., family involvement definition and publication characteristics). Neither the moderating hypotheses nor the direct-effect of family involvement in ownership were supported. However, they suggest future research to examine new moderators on the proposed relationship in order to break down the findings' puzzle. In the same vein, Barth, Gulbrandsen, and Schone (2005) suggested that future researchers concentrate on who runs the firm as opposed to who owns it; many supports 
have been reported for the impact of family ownership on the firms' performance. One possible explanation for why the results were inconsistent may be related to the lack of understanding of the moderating effect of a family CEO and founder CEO. Jiang and Peng (2011) were the only ones who investigated the moderating effect of family CEOs on the family ownership-firm performance relationship in Asia, in which family CEOs were found to positively moderate the relationship in some countries (e.g., Indonesia and Taiwan), and negatively moderate the relationship in Hong Kong. However, their study has clearly neglected the moderating impact of founder CEOs on the relationship, which in turn, limits our understanding on the effect of family involvement on firm performance.

Based on the above rationale, this study concentrates on examining the moderating effect of founder CEO along with the moderating effect of family CEO on the relationship between family ownership and firm performance, as suggested by Jiang and Peng (2011). It is hypothesized that family firms whose dominant family shareholder (founder) is the CEO outperform their non-family (non-founder) counterparts. The hypothesis is in line with the spirit of prior studies (e.g., Anderson \& Reeb, 2003; Villalonga \& Amit, 2006) and the evidence provided by Jiang and Peng (2011).

The main purpose of this study is to extract new evidence from a blooming emerging area in the world, specifically the Gulf Cooperation Council (GCC). We construct five research hypotheses. Three of them are created to test the direct effects of family ownership, family CEO and founder CEO on two firm performance indicators (ROA and MBV), and the remaining two are developed in order to examine the moderating effect of family CEO and founder CEO on the relationship between family ownership and firms performance. Employing a sample of 75 non-financial public listed companies in Saudi Arabia from 2007 to 2011 (yielding 375 firm-year observations), the findings show that family firms outperform their non-family counterparts in terms of ROA. However, we find no evidence to support the hypothesis that there is a direct effect of family CEO on ROA and MBV. With regard to the moderating effect of family CEO, the results were significant only when MBV was used to measure firm performance. However, the results failed to provide sufficient evidence on its moderating effect when only family firms were considered in the analyses. In terms of founder CEO, the hypotheses of its direct effect as well as moderating effect have been significantly supported, even when non-family firms were dropped from the sample. These findings are robust and support the previous theoretical and empirical studies on the positive role of founders on firm performance.

\section{Literature Review and Hypotheses Development}

\subsection{Family Ownership}

Jensen and Meckling (1976) offered several techniques of corporate control affecting organizations' achievement of objectives, and among them is the ownership structure. It is a crucial technique, particularly in firms owned by a family or by a group of families. This is because the firms' objectives are interrelated with those of the family and owners who are protecting the family agenda by maintaining the independence of their company.

It is a common belief that the alignment between the controlling family's interests and the other shareholders' interests is superior in family businesses, owing to the family's dominant ownership and their long-term existence (Wang, 2005). This led to numerous studies that examined the link between family ownership and firm performance. However, the results have so far been ambiguous (Sciascia \& Mazzola, 2008).

According to Berle and Means (1932), the ownership concentration in the blockholders' hands affects firms' value in a positive way as it works to decrease the agency cost that may arise between the firm management and the shareholders. Hence, Jensen and Meckling (1976) recommended that family firm is a good model to reduce this type of cost as owner's interest, concentrating on family relations, is typically aligned with the manager's interest of concentrating on both profitability and competitive advantage (Villalonga \& Amit, 2006). This will invariably result in the maximization of shareholders' wealth (Seifert, Gonenct, \& Wright, 2005).

In the same vein, Anderson and Reeb (2003) revealed that family businesses in the U.S. outperformed their non-family counterparts while Lee (2006) evidenced that family firms displayed superior performance in the context of revenue, income growth, and net profit margin in the long-term. In a related study, Maury (2006) investigated the relationship between family ownership and firm performance of eleven Western European countries and revealed that family ownership positively affects firm profitability in terms of ROA, particularly in economies having stringent regulations. In addition, Barontini and Caprio (2006) demonstrated that family firms listed in eleven Continental Europe countries have superior performance in terms of ROA and Tobin's Q. Ben-Amar and Andre (2006) show similar findings in the context of Canada. They revealed that family creation has a positive role in value creation. In Chile, Martinez, Stohr, and Quiroga (2007) also provided evidence on the outperformance of public listed family firms in terms of firm's profitability (ROA). In the context of Asian 
countries, several studies provide evidence of the superior performance of family businesses (Saito, 2008; Amran \& Che-Ahmad, 2010). Family firms in Arab countries are no exception to the outperformance (see for example Al-Dubai, Ku Ismail, \& Amran, 2014).

Nonetheless, family owners holding a majority of the voting shares are likely to have personal interests and will use their power to take private advantage by appropriating resources to companies owned by them or other family members, hence expropriating the rights of the minority shareholders (La Porta, Lopez-de-Silanes, \& Shleifer, 1999; Claessens, Djankov, \& Lang, 2000; Schulze, Lubatkin, Dino, \& Buchholtz, 2001; Villalonga \& Amit, 2006). According to Corbetta and Salvato (2004), the agency problem (Agency cost II) does occur between family members and minority shareholders although the conflict of interest is low, if not negligible, in privately held firms. However, it tends to be high in the case of publicly listed family firms or in firms wherein external entities have a hand in ownership.

Gallo, Tapies, and Cappuyns (2004) revealed a contrary finding in their study involving 305 Spanish firms. They showed that although family firms achieved lower leverage and debt ratios, their sales/assets ratio was higher. Examining firms in the United Arab Emirates, Majumdar and Varadarajan (2012) found that Tobin's Q of family firms is statistically lower than that of non-family firms. Faccio, Lang, and Young (2001) argued that family-held firms display poor performance because of their intention to possess and control firm positions.

On the other hand, Demsetz and Villalonga (2001) who investigated 223 firms taken from the sample of Demsetz and Lehn's (1985) revealed that there is no significant link between ownership structure and firm value (Tobin's Q). The finding is consistent with the earlier study by Demsetz and Lehn (1985) which showed no significant relationship between ownership concentration and accounting profit rates. In the context of non-listed private firms, Westhead and Howorth (2006) and Sciascia and Mazzola (2008) also showed no evidence of a significant relationship between family involvement in ownership and firm performance. Further, Miller, Le Breton-Miller, Lester, and Cannella (2007) found that family firms are successful on the overall when lone founder-controlled firms were included in the analysis, but when this type of firms are excluded from family firm definition, the effect became insignificant. Based on the above discussion, the following hypothesis is proposed:

\section{H1: Family firms outperform their non-family counterparts}

\subsection{The Moderating Effect of Family CEO}

Issues concerning corporate governance and ownership separation were first highlighted by Berle and Means (1932). Since then, various researchers have tackled the topic in order to examine and find solutions to the issues. The majority of the studies utilized agency theory as their theoretical basis (Mustakallio, 2002), as it offers an extensive framework that clarifies the conflicting interest among owners and managers. However, despite the many studies dedicated to the examination of the relationship between family involvement in management and firm performance, contradictory findings were reached by some authors (Kowalewski, Talavera, \& Stetsyuk, 2010; Sciascia \& Mazzola, 2008). This stems from the contrasting viewpoints of the agency theory and stewardship theory and the implications they have on family firms.

The agency theory postulates that the absence of interest-convergence among shareholders holding a part of the firm's ownership and external managers significantly increases the agency cost (Jensen \& Meckling, 1976). The reason lies in the fact that according to the agency theory, managers are self-interested individuals (Davis, Schoorman, \& Donaldson, 1997), driven by personal ego (Ramachandran \& Jha, 2007) who act mainly in their own best interests, forsaking the interests of other shareholders and carry out activities that go against the maximization of shareholder's wealth. Hence, to reduce the agency problem, managers also have to be owners, so that maximum efforts can be expended for the improvement of firm value (Seifert et al., 2005) or for family to be involved in both ownership and management (Bocatto, Gispert, \& Rialp, 2010).

Several researchers (Maury \& Pajuste, 2005; Sciascia \& Mazzola, 2008) examined the family involvement in the management of family firms. Owing to the family's legacy being one and the same with the firm's welfare, family owners are often disinclined to relinquish their power to external managers. Hence, family owners may block non-family members from gaining key managerial positions in the company (Westhead \& Howorth, 2006). Moreover, family owners opt to keep the decision making process in their hands (Ward, 1987) to prevent the occurrence of any conflict between them and external managers that would consequently impact the performance of the firm in a negative way (Chua, Chrisman, \& Sharma, 2003). This scenario is present in the Arab family businesses and most family businesses have their management in the hands of family members (Al Masah, 2011).

In addition, family CEOs help to align family shareholders' incentives with managers' incentives, which 
eventually results in positive firm performance (Anderson \& Reeb, 2003). This alignment can be achieved through the goal alignment between owners and managers (Davis et al., 1997), manager's identification with the firm (Block, 2010), and family managers' trustworthiness, as postulated by the stewardship theory (Dalton, Daily, Ellstrand, \& Johnson, 1998). Hence, a family member has more chance of being a CEO as opposed to non-family members in family firms owing to their alleviation of agency cost and provision of support to family control (Jiang \& Peng, 2011).

Contrary to the above, Her and Williams (2002) revealed that CEOs of Taiwanese descendant-controlled firms that have a majority of family directors and supervisors are inclined to participate in managerial entrenchment in a way that family CEOs often transfer firms' wealth or resources to their own family members. However, Anderson and Reeb (2003) revealed that firms with family CEOs outperform their counterparts in terms of profitability, a finding supported by Lee (2006) and Isakov and Weisskopf (2009). Based on Isakov and Weisskopf's (2009) study, the performance of family firms with external CEOs is inferior compared to those with family CEOs in the context of accounting performance (ROA). In Continental Europe, family firms with family CEOs show a better performance comparing to family firms with non-family CEOs, even though the relationship is weak (i.e., probability of the coefficient is lower than the $10 \%$ level of significance) (Barontini \& Caprio, 2006).

Similarly, Lee (2006) revealed that family firms underperform non-family firms with the exception of situations where family members were CEOs. According to Block (2010), this is because of management's identification with the firm. When the CEOs have greater identification and possess more incentive not to employ actions that may tarnish the firm's reputation, their identification encourages them to expend effort and work together for the protection of the welfare and reputation of both the family and firm.

The mixed findings regarding family ownership and firm performance, as shown by prior studies, highlight the complexity of the relationship that seems to be moderated by other factors (Mazzi, 2011). The key limitation of prior studies is that they failed to study the level to which the family CEOs and their generation moderate the relationship between ownership and performance. Based on the study by Anderson and Reeb (2003), the positive accounting performance and greater market value displayed by family businesses are perpetuated by the family CEO at the helm. In their own words, "the greater profitability in family firms, relative to non-family, stems from those firms in which a family member serves as the CEO" (Anderson \& Reeb, 2003, p. 1324). Similarly, Villalonga and Amit (2006) presented that family ownership only develops value in situations where the founder is the CEO of the firm and this value dissipates once the descendants take the founder's place as the CEO.

In another related study, Jiang and Peng (2011) showed that family ownership does not significantly relate to firm performance. Further analysis showed that through the interaction of family CEO with family ownership, family CEO was found to positively moderate the impact of family ownership upon firm performance in the context of Indonesia and Taiwan. However, it negatively moderates the relationship in the context of Hong Kong. Hence, from the above discussion, the following are hypothesized:

H2a: Family firms managed by family CEOs outperform companies not managed by family CEOs.

H2b: Family CEO moderates the relationship between family ownership and firm performance.

\subsection{The Moderating Effect of Founder CEO}

McConaughy and Phillips (1999) examined family generation differences in their effect on performance. According to them, "both theory and former empirical research suggest the occurrence of the so-called "founder effect', meaning that the performance of family firms is particularly strong when the founder is still active as CEO" (Andres, 2008, p. 439). Similarly, Burkart, Panunzi, and Shleifer (2003) posited that a professional is more able compared to the descendant when it comes to being firm CEO.

However, empirical findings show that founder and descendant CEOs have a varying effect on firm performance owing to their different behaviour (Sacristan-Navarro et al., 2011) with the firm performance being superior with a founder-CEO (e.g., Morck, Shleifer, \& Vishny, 1988; Villalonga \& Amit, 2006; Adams, Almeida, \& Ferreira, 2009). This view is supported by Andres (2008) who investigated the founder effect on the performance of listed companies in Germany and revealed the superior performance of family firms that are managed by founder CEOs in the context of accounting performance measured by ROA. Using Tobin's Q as a measure, descendant CEOs and external CEOs in family firms and CEOs in non-family business perform on a similar level.

However, Burkart et al. (2003) hypothesize that in a family firm, a suitable action is to employ an external CEO as opposed to allowing the descendant of the founder to hold the helm of the business. The hypothesis is supported by different sets of findings. Smith and Amoako-Adu (1999), and Perez-Gonzalez (2006) revealed a 
negative reaction of the stock market to the announcement of the appointment of descendant CEOs in the U.S. and Canada. The result of these studies imply a positive reaction to founder CEOs as opposed to descendant CEOs, as the former employs disclosure behaviour in an efficient way compared to non-family firms (Ali, Chen, \& Radhakrishnan, 2007).

On the whole, prior studies posited that founders develop their businesses for countless reasons, such as making a living, providing secure jobs for the members of their family, improve quality of life and so forth. They are always concerned with their vision for the evolution of the business from its inception along with other issues, such as the business survival, and protection of family legacy for the coming generations (Zahra, 2005). When a descendant takes the place of the founder as a CEO, the firm value dissipates as they "face different challenges to maintain and enhance the business and these tasks may be better performed in a more professional manner, often by non-family members" (Sonfield \& Lussier, 2004, p. 191). Therefore, based on the above discussion of prior findings, the following hypotheses are postulated:

H3a: Family firms managed by founder CEOs outperform companies not managed by founder CEOs.

H3b: Founder CEOs moderate the relationship between family ownership and firm performance.

\section{Research Methods}

In order to test the hypotheses, we conduct a cross-sectional time-series analyses as suggested by a number of researchers (e.g., Sciascia, Mazzola, Astrachan, \& Pieper, 2012).

\subsection{Sample Selection}

As this study aims to extract new evidence from the context of GCC countries, we focus on companies that are non-financial and public listed in Saudi Stock Exchange, commonly known as Tadawul. Financial firms like banks and insurance were dropped from the sample because of the different accounting and governmental regulations (Alsaeed, 2006; Claessens \& Djankov, 1999; Isakov \& Weisskopf, 2009; Lee, 2006). Consequently, any comparison between the performance measures of financial and non-financial institution will not be fair and applicable (Martinez et al., 2007). Observing for a period of five years (2007-2011), the final sample consists of 75 public traded firms, involving 375 firm-year observations. We compile our financial and non-financial data from various resources include the website of the Saudi Stock Exchange (www.tadawul.com.sa), audited annual reports, Thomson DataStream and Aljoman.net. We supplement any missing data by using other online resources such as Zawya.com, Gulfbase.com, and Argaam.com.

\subsection{Empirical Model}

The research models to be estimated are discussed as follows:

1- Direct-effect model:

$$
\begin{aligned}
\text { Firm performance }= & \alpha_{0}+\beta_{1}(\text { family ownership })_{\mathrm{it}}+\beta_{2}(\text { family CEO })_{\mathrm{it}}+\beta_{3}(\text { founder CEO })_{\mathrm{it}}+ \\
& \beta_{4}(\text { firm debt })_{\mathrm{it}}+\beta_{5}(\text { firm age })_{\mathrm{it}}+\beta_{6}(\text { firm size })_{\mathrm{it}}+\beta_{7}(\text { industry dummies })_{\mathrm{it}}+\mu_{i}+\varepsilon_{i t}
\end{aligned}
$$

2- Moderating effect model:

$$
\begin{aligned}
\text { Firm performance }= & \alpha_{0}+\beta_{1}(\text { family ownership })_{\text {it }}+\beta_{2}(\text { family CEO })_{\text {it }}+\beta_{3}(\text { founder CEO })_{\text {it }}+ \\
& \beta_{4}(\text { family ownership*family CEO })_{\text {it }}+\beta_{5}(\text { family ownership*founder CEO })_{\text {it }}+ \\
& \beta_{6}(\text { firm debt })_{\text {it }}+\beta_{7}(\text { firm age })_{\text {it }}+\beta_{8}(\text { firm size })_{\text {it }}+\beta_{9}(\text { industry dummies })_{\text {it }}+\mu_{i}+\varepsilon_{i t}
\end{aligned}
$$

Firm performance is measured by two indicators: market-based indicator, namely Market-to-Book Value (MBV) and accounting-based indicator, Return on Assets (ROA). We measure MBV as the market value (the year-end closing share price multiply by the number of shares ) divided by the book value of common shares (Beiner, Drobetz, Schmid, \& Zimmermann, 2006; yeh, 2005). ROA is calculated as the net income divided by the book value of total assets (Anderson \& Reeb, 2003; Perez-Gonzalez, 2006). Family ownership is a ratio of family-owned shares to the total firm's shares (Anderson \& Reeb, 2003). Following Al-Dubai et al. (2014), we define a firm as family firm if the controlling shareholder owns at least $5 \%$ of the firm's shares and at least one of his relatives by blood (i.e. sharing his surname) serves either as $\mathrm{CEO} /$ Chairman or occupies a position in board of the directors. Family CEO is a dummy variable that takes the value of 1 if the $\mathrm{CEO}$ is a family member, otherwise 0 for non-family CEO (Anderson \& Reeb, 2003; Barontini \& Caprio, 2006; Ben-Amar \& Andre, 2006; 
Villalonga \& Amit, 2006; Isakov \& Weisskopf, 2009; Kowalewski et al., 2010; Jiang \& Peng, 2011; Sacristan-Navarro et al., 2011). Founder CEO is a dummy that takes the value of 1 if the CEO position was occupied by the founder, otherwise 0 (Andres, 2008; Adams et al., 2009). Two interaction terms have been created: family ownership*family CEO and family ownership*founder CEO to represent the moderating effect of family CEO and founder CEO on the relationship between family ownership and firm performance. Firm debt is a ratio of the book value of long-term debt to total assets (Anderson \& Reeb, 2003; Martinez et al., 2007). Firm age is calculated as the natural log of the number of years since the firm's inception (Anderson \& Reeb, 2003; Martinez et al., 2007; Andres, 2008; Adams et al., 2009; Isakov \& Weisskopf, 2009; Sacristan-Navarro et al., 2011). Firm size is measured as the natural $\log$ of the book value of total assets (Anderson \& Reeb, 2003; Martinez et al., 2007; Sacristan-Navarro et al., 2011). Industry dummies includes eight dummies representing the nine industry sectors that are petrochemical, cement, retail, agriculture and food, multi-investment, industrial investment, building and construction, real estate development, and other sectors.

$\alpha_{0}, \mu_{i}$, and $\varepsilon_{i t}$ are the constant, the unobserved firm-level random effect, and the idiosyncratic error, respectively.

\subsection{Analysis}

To test for heteroscedasticity and autocorrelation in panel data, we used Breusch-Pagan/Cook-Weisberg and Wooldridge tests respectively. The tests show that MBV model suffers from heteroscedasticity $(\operatorname{chi} 2=77.41, p$ $<0.00)$ and autocorrelation $(F=12.73, p<0.00)$ problems, while ROA model is homoscedastic and not correlated Therefore, FGLS random-effects model is used to control for heteroscedasticity and autocorrelation in the MBV model, using STATA.

\section{Results and Discussion}

Table 1 presents the characteristics of our sampled firms. The total sample encompasses 375 firm-years, of which 212 (56.5 percent) are family firms and the remaining are non-family firms. Out of the 212 family firms, only 30 (14.2 percent) of them have family CEOs. A majority of family firms ( 85.8 percent) have non-family CEOs (professionals). This is contrary to the notion that the tendency of family firms is to recruit a large pool of family members in the top key managerial positions. This indicates that Saudi family businesses change their propensity of employing family members as CEOs when they go public to ensure the professionalism of the management. The above findings are in line with the study by Anderson and Reeb (2003) in the U.S. and in contrast with findings of Ben-Amar and Andre (2006) in Canada. With regard to founder CEO, the results show that the majority of family CEOs are non-founders (94.3 percent) and only 12 (5.7 percent) of the family firms have their founders as CEOs. This indicates that the decision making process of the majority of family businesses is less centralized and the CEOs tend to adopt a more professional style of management, in comparison with more paternalistic, informal, and subjective management style and culture in founder-CEO family firms (Sonfield \& Lussier, 2004).

Table 1. Firm characteristics

\begin{tabular}{|c|c|c|c|c|c|c|}
\hline & \multicolumn{2}{|c|}{ All Firms $(n=375)$} & \multicolumn{4}{|c|}{ Family Firms $(n=212)$} \\
\hline & Family & Non_Family & Family & Non-Family & Founder & Non-Founder \\
\hline & 1 antाy & 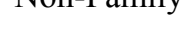 & CEO & CEO & CEO & CEO \\
\hline Number & 212 & 163 & 30 & 182 & 12 & 200 \\
\hline Percent & 56.5 & 43.5 & 14.2 & 85.8 & 5.7 & 94.3 \\
\hline
\end{tabular}

The descriptive statistics are displayed in Table 2. We found that the performance between family and non-family firms is significantly different. The results show that family firms, on average, are better performers than non-family firms in terms of return on assets (ROA: 0.07 versus 0.05 ) but have a lower market performance (MBV: 1.66 versus 1.95 ). Firm's debt, age, and size are also statistically distinguishable between family and non-family firms. Family firms are shown to be older, have higher average of debt and smaller than their non-family counterparts. This is in line with the findings of Anderson and Reeb (2003) for firm age but contrary in terms of firm's debt and size. 
Table 2. Summary statistics for the full sample

\begin{tabular}{lllllll}
\hline & \multicolumn{2}{l}{ All Firms $(\mathrm{n}=375)$} & & & \\
& Mean & Median & Std. Dev. & Family Firm $(\mathrm{n}=212)$ & Non-Family Firm $(\mathrm{n}=163)$ & t-statistics \\
\hline ROA & 0.07 & 0.06 & 0.09 & 0.07 & 0.05 & $-2.31^{* *}$ \\
MBV & 1.78 & 1.40 & 1.18 & 1.66 & 1.95 & $2.38^{* *}$ \\
Firm Debt & 0.14 & 0.08 & 0.15 & 0.15 & 0.12 & $-2.22^{* *}$ \\
Firm Age & 24.41 & 23.00 & 12.53 & 26.67 & 21.48 & $-4.05^{* * *}$ \\
Firm Size & 10,000 & 1,800 & 39,000 & 3,900 & 19,000 & $3.71^{* * *}$ \\
Family Ownership & 0.13 & 0.07 & 0.18 & - & - & - \\
Family CEO & - & - & - & - & - & - \\
Founder CEO & - & - & - & - & - & - \\
\hline
\end{tabular}

Note: Firm size is total assets expressed in millions of Saudi Riyals. ${ }^{*} \mathrm{p}<0.10,{ }^{* *} \mathrm{p}<0.05,{ }^{* * *} \mathrm{p}<0.01$

Table 3 exhibits the correlation among the variables of the study. It shows that except firm debt, all other explanatory and control variables are significantly and positively associated with ROA. In terms of MBV, family $\mathrm{CEO}$, founder CEO, and firm age are significantly and positively related to MBV. Family ownership is not significantly associated with MBV. In contrast, firm debt and firm size have a negative relationship with MBV and significant at a 1 percent level. The tables also shows that multi-collinearity is not a matter of concern in this study, since the maximum value of the observed variance inflation index (VIF) is far below 10, the value suggested by Hair, Black, Babin, and Anderson (2010) as an indicator of a multi-collinearity problem.

Table 3. Correlations among variables

\begin{tabular}{|c|c|c|c|c|c|c|c|c|c|}
\hline & ROA & MBV & $\begin{array}{l}\text { Family } \\
\text { Ownership }\end{array}$ & $\begin{array}{l}\text { Family } \\
\text { CEO }\end{array}$ & $\begin{array}{l}\text { Founder } \\
\text { CEO }\end{array}$ & $\begin{array}{l}\text { Firm } \\
\text { Debt }\end{array}$ & $\begin{array}{l}\text { Firm } \\
\text { Age }\end{array}$ & $\begin{array}{l}\text { Firm } \\
\text { Size }\end{array}$ & VIF \\
\hline $\mathrm{ROA}$ & 1.00 & & & & & & & & \\
\hline MBV & $0.20 * * *$ & 1.00 & & & & & & & \\
\hline $\begin{array}{l}\text { Family } \\
\text { Ownership }\end{array}$ & $0.20 * * *$ & 0.00 & 1.00 & & & & & & 1.26 \\
\hline Family CEO & $0.19 * * *$ & $0.10 *$ & $0.35 * * *$ & 1.00 & & & & & 2.05 \\
\hline Founder CEO & $0.22 * * *$ & $0.20 * * *$ & $0.27 * * *$ & $0.62 * * *$ & 1.00 & & & & 1.74 \\
\hline Firm Debt & $-0.10^{*}$ & $-0.22 * * *$ & -0.05 & -0.04 & -0.06 & 1.00 & & & 2.12 \\
\hline Firm Age & $0.23 * * *$ & $0.12 * *$ & 0.03 & $0.17 * * *$ & 0.15 & $-0.21 * * *$ & 1.00 & & 1.39 \\
\hline Firm Size & $0.15 * * *$ & $-0.39 * * *$ & -0.04 & 0.03 & -0.05 & $0.58 * * *$ & $-0.13 * *$ & 1.00 & 2.00 \\
\hline
\end{tabular}

\subsection{Multivariate Results}

Results of the panel data analysis are presented in Table 4. Panel 1 explains for overall sample (i.e. family and non-family firms), and Panel 2 for family firms only as a further test. According to Fairchild and McQuillin (2010), Braumoeller (2004), and Jaccard and Turrisi (2003), any conclusions regarding the direct effect of any constitutive terms are meaningless and illegitimate. Hence, every firm's performance indicator was examined in two models (columns): the first column is created to test the direct relationship hypotheses (H1, $\mathrm{H} 2 \mathrm{a}$, and $\mathrm{H} 3 \mathrm{a}$ ) while the purpose of the second one is to test the interactive (moderating) effect of the two variables: family $\mathrm{CEO}$ and Founder CEO (H2b and $\mathrm{H} 3 \mathrm{~b})$.

Hypothesis 1 predicts the outperformance of family firms relative to non-family firms. The findings in column 1 (Model 1) of MBV and ROA are contradictory. While family ownership had a positive effect on ROA $(\beta=0.078$, $\mathrm{p}<0.10$ ), the effect was not significant with market performance (MBV). The results are in line with those of developed countries like the U.S. (Anderson \& Reeb, 2003; Lee, 2006), Japan (Saito, 2008), Canada (Ben-Amar \& Andre, 2006), and studies in emerging economies such as Saudi Arabia (Al-Dubai et al., 2014) and Malaysia (Amran \& Che-Ahmad, 2010) but differ from some others (e.g., Miller et al., 2007). In general, the findings support the common belief of the success of the controlling family owner to align between family's interests and other shareholders' interests as argued by Berle and Means (1932) and Jensen and Meckling (1976). A possible explanation is that, when family firms become large and publicly traded, family controlling shareholders would not concentrate only on their private benefits but instead they pay more attention to keep other shareholders' 
rights from being expropriated. Consequently, family firms perform better. Thus, Hypothesis 1 is partially confirmed.

Model 1 of Table 4 shows that family CEO and founder CEO are not associated with ROA. This finding is consistent with some previous empirical studies which reveal that family CEO has no direct significant impact on neither accounting performance of the firm (ROA) (Barontini \& Caprio, 2006) nor firm value (Barontini \& Caprio, 2006; Jiang \& Peng, 2011). However, we find that under the MBV model (Model 3), founder CEO is significantly and positively associated with MBV $(\beta=0.782, \mathrm{p}<0.10)$. This confirms the positive role of the founder in his own firm. Hence, H2a is not supported and H3a is partially supported.

In testing the moderating effect of family $\mathrm{CEO}$ and founder $\mathrm{CEO}$ on the relationship between family ownership and firm performance, the two multiplicative terms (Family Ownership*Family CEO and Family Ownership*Found CEO) are significantly positive at the 5 percent level when the dependent variable was MBV (Model 4). This indicates that family CEO and founder CEO positively moderates the effect of family ownership on the market performance (MBV). In other words, principal-agent problem is more likely to exist and costly in family firms whose CEOs are non-family (non-founders) members. In magnitude, the coefficient of founder $\mathrm{CEO}$ is higher than that of family CEO. Thus, the evidence suggests that a significant portion of firm performance is attributable to the positive role of the founders in their own firms. The findings are consistent with those of Jiang and Peng's (2011) study whereby a positive moderating impact of family CEO is evidenced for some of Asian countries such as Indonesia and Taiwan. The results suggest that family firms must be cautious about CEO positions and the individuals they appoint.

As for the control variables, it was found that firm debt does affect ROA negatively, which means that a firm with low level of debt perform better than a firm with a higher debt. In contrast, firm size positively affects ROA, indicating that larger firms perform better financially compared to their smaller counterparts. For MBV, both control variables (firm age and firm size) have a negative impact on market performance.

\subsection{Further Analyses}

In order to support our conclusions, we conducted some robustness tests. We spilt our data, keeping only the family firms (208 firm-year observation). Except for the ROA models, the results remained the same. As can be seen from Panel 2 of Table 4, family ownership variable is positively related to both performance indicators, but significant at the 5\% level in ROA (Model 5). This means that a $1 \%$ increase in family ownership enhances the return on the assets of the firm by about $8 \%$. To confirm the hypothesised positive role of the firms' founders in Hypotheses 2a and 3a, the findings of models 5 and 7 show that founder CEO positively impacts the ROA and MBV at the 5 and $1 \%$ level of significance, respectively. With regard to the moderating effects of family CEO and founder CEO, we found that only founder CEO positively moderates the relationship between both ROA and MBV on one side, and family ownership on the other side. In light of these results, we conclude that family firms whose CEOs are founders would perform better than their counterparts with non-founder CEOs.

Table 4. Results of cross-sectional time-series analyses

\begin{tabular}{|c|c|c|c|c|c|c|c|c|}
\hline \multirow{3}{*}{ Variables } & \multicolumn{4}{|c|}{ Panel 1: Overall sample } & \multicolumn{4}{|c|}{ Panel 2: Family firms only } \\
\hline & \multicolumn{2}{|c|}{ ROA } & \multicolumn{2}{|l|}{ MBV } & \multicolumn{2}{|l|}{ ROA } & \multicolumn{2}{|l|}{ MBV } \\
\hline & $\begin{array}{l}\text { Model } \\
\text { (1) }\end{array}$ & $\begin{array}{l}\text { Model } \\
\text { (2) }\end{array}$ & Model (3) & Model (4) & $\begin{array}{l}\text { Model } \\
\text { (5) }\end{array}$ & $\begin{array}{l}\text { Model } \\
\text { (6) }\end{array}$ & Model (7) & Model (8) \\
\hline \multirow{2}{*}{ Constant } & $-0.211^{*}$ & $-0.208^{*}$ & $7.380 * * *$ & $7.315^{* * *}$ & 0.005 & 0.014 & $5.262 * * *$ & $5.574 * * *$ \\
\hline & $(-1.72)$ & $(-1.73)$ & $(9.51)$ & $(9.64)$ & $(0.04)$ & $(0.12)$ & $(4.39)$ & $(4.66)$ \\
\hline \multirow{2}{*}{ Family Ownership } & $0.078^{*}$ & $0.077^{*}$ & -0.122 & -0.384 & $0.076^{* *}$ & 0.054 & 0.164 & -0.085 \\
\hline & $(1.84)$ & $(1.71)$ & $(-0.48)$ & $(-1.45)$ & $(2.17)$ & $(1.45)$ & $(0.55)$ & $(-0.27)$ \\
\hline \multirow{2}{*}{ Family CEO } & 0.022 & 0.042 & 0.402 & -0.336 & 0.000 & 0.011 & 0.209 & -0.121 \\
\hline & $(0.61)$ & $(0.73)$ & $(1.58)$ & $(-0.90)$ & $(0.01)$ & $(0.31)$ & $(0.88)$ & $(-0.33)$ \\
\hline \multirow{2}{*}{ Founder CEO } & 0.044 & -0.023 & $0.782 *$ & -0.503 & $0.060 * *$ & -0.031 & $1.115^{* * *}$ & -0.752 \\
\hline & $(1.14)$ & $(-0.32)$ & $(1.92)$ & $(-0.75)$ & $(2.21)$ & $(-0.61)$ & $(2.81)$ & $(-1.03)$ \\
\hline $\begin{array}{l}\text { Family } \\
\text { Ownership*Family } \\
\text { CEO }\end{array}$ & - & $\begin{array}{l}-0.082 \\
(-0.52)\end{array}$ & - & $\begin{array}{l}2.220 * * \\
(2.15)\end{array}$ & - & $\begin{array}{l}-0.032 \\
(-0.34)\end{array}$ & - & $\begin{array}{l}1.158 \\
(1.07)\end{array}$ \\
\hline $\begin{array}{l}\text { Family } \\
\text { Ownership*Found }\end{array}$ & - & $\begin{array}{l}0.242 \\
(1.10)\end{array}$ & - & $\begin{array}{l}4.059 * * \\
(1.99)\end{array}$ & - & $\begin{array}{l}0.294 * * \\
(2.05)\end{array}$ & - & $\begin{array}{l}5.288^{* *} \\
(2.51)\end{array}$ \\
\hline
\end{tabular}




\begin{tabular}{|c|c|c|c|c|c|c|c|c|}
\hline \multirow{3}{*}{ CEO } & \multicolumn{4}{|c|}{ Panel 1: Overall sample } & \multicolumn{4}{|c|}{ Panel 2: Family firms only } \\
\hline & \multicolumn{2}{|c|}{ ROA } & \multicolumn{2}{|l|}{ MBV } & \multicolumn{2}{|c|}{ ROA } & \multicolumn{2}{|l|}{ MBV } \\
\hline & & & & & & & & \\
\hline Firm Debt & $\begin{array}{l}-0.106 * * \\
(-2.55)\end{array}$ & $\begin{array}{l}-0.109^{* * *} \\
(-2.62)\end{array}$ & $\begin{array}{l}0.056 \\
(0.19)\end{array}$ & $\begin{array}{l}-0.006 \\
(-0.02)\end{array}$ & $\begin{array}{l}-0.041 \\
(-1.03)\end{array}$ & $\begin{array}{l}-0.042 \\
(-1.08)\end{array}$ & $\begin{array}{l}0.496 \\
(1.63)\end{array}$ & $\begin{array}{l}0.502 \\
(1.61)\end{array}$ \\
\hline Firm Age & $\begin{array}{l}0.004 \\
(0.40)\end{array}$ & $\begin{array}{l}0.005 \\
(0.52)\end{array}$ & $\begin{array}{l}-0.176^{* * *} \\
(-3.03)\end{array}$ & $\begin{array}{l}-0.174 * * * \\
(-3.06)\end{array}$ & $\begin{array}{l}-0.004 \\
(-0.43)\end{array}$ & $\begin{array}{l}-0.005 \\
(-0.56)\end{array}$ & $\begin{array}{l}-0.347 * * * \\
(-4.05)\end{array}$ & $\begin{array}{l}-0.367^{* * *} \\
(-4.32)\end{array}$ \\
\hline Firm Size & $\begin{array}{l}0.011^{*} \\
(1.96)\end{array}$ & $\begin{array}{l}0.011^{*} \\
(1.95)\end{array}$ & $\begin{array}{l}-0.253^{* * *} \\
(-7.21)\end{array}$ & $\begin{array}{l}-0.249^{* * *} \\
(-7.30)\end{array}$ & $\begin{array}{l}0.003 \\
(0.54)\end{array}$ & $\begin{array}{l}0.004 \\
(0.58)\end{array}$ & $\begin{array}{l}-0.140^{* *} \\
(-2.29)\end{array}$ & $\begin{array}{l}-0.149 * * \\
(-2.47)\end{array}$ \\
\hline Industry Dummies & Included & Included & Included & Included & Included & Included & Included & Included \\
\hline$N$ & 375 & 375 & 375 & 375 & 208 & 208 & 208 & 208 \\
\hline$R^{2}$ & 0.36 & 0.37 & 0.28 & 0.29 & 0.50 & 0.53 & 0.28 & 0.33 \\
\hline Wald chi ${ }^{2}$ & 58.89 & 63.32 & 161.03 & 205.26 & 88.47 & 106.50 & 153.84 & 180.62 \\
\hline Prob $>F$ & 0.00 & 0.00 & 0.00 & 0.00 & 0.00 & 0.00 & 0.00 & 0.00 \\
\hline
\end{tabular}

Note: Figure in the parenthesis is (z value) for MBV and ROA models, ***significant at $1 \%$ level (2 tailed), **significant at $5 \%$ level ( 2 tailed), *significant at $10 \%$ level ( 2 tailed).

\section{Conclusion}

In a nutshell, this study aims to provide fresh evidence from GCC emerging market on the effect of family involvement in ownership and management (family CEO and founder CEO) on firm accounting and market performance. More importantly, we test if family CEO and founder CEO moderate the relationship between family ownership and firm performance. We provide evidence of a positive relationship between family ownership and founder CEO on ROA and MBV. However, the moderating effect of family CEO and founder $\mathrm{CEO}$ on the relationship between family ownership and firm performance could only be observed in the case of MBV. The results are robust when only family firms are considered in the analyses.

The study had shed some light on family firm performance in the context of GCC countries. This study primarily confirms the distinct role of the founders in their outperformed firms. In this regard, a key implication of these findings is that Capital Market Authority (CMA) and Saudi Arabian Monetary Agency (SAMA) should formulate laws that impose public listed companies to disclose, in their corporate governance reports, information such as type of the firm (i.e. family or non-family) and the kind of relationship that ties between the owners, managers and directors (i.e. familial or non-familial). However, further research is necessary in order to confirm the performance of family firms in other Arab countries that are non-GCC countries. Employing different performance indicators is also worth a study. As this paper mainly focuses on the moderating effect of family involvement in management (i.e. family CEO and founder CEO) on the relationship between family involvement in ownership and firm performance, the paper can be extended by including other moderators, such as family control (i.e. family involvement on the board of directors) and the presence of other blockholders.

\section{References}

Adams, R., Almeida, H., \& Ferreira, D. (2009). Understanding the relationship between founder-CEOs and firm performance. Journal of Empirical Finance, 16(1), 136-150. http://dx.doi.org/10.1016/j.jempfin.2008.05. 002

Al Masah. (2011). MENA Family Businesses: The Real Power Brokers? Dubai, UAE: Al Masah Capital Management Limited.

Al-Dubai, S. A. A., Ku Ismail, K. N. I., \& Amran, N. A. (2014). Family Business Definition: A Matter of Concern or a Matter of Convenience? Corporate Ownership \& Control, 11(2), 274-280.

Ali, A., Chen, T. Y., \& Radhakrishnan, S. (2007). Corporate disclosures by family firms. Journal of Accounting and Economics, 44(1-2), 238-286. http://dx.doi.org/10.1016/j.jacceco.2007.01.006

Alsaeed, K. (2006). The association between firm-specific characteristics and disclosure. Managerial Auditing Journal, 21(5), 476-496. http://dx.doi.org/10.1108/02686900610667256

Amran, N. A., \& Che-Ahmad, A. (2010). Family Succession and Firm Performance among Malaysian Companies. International Journal of Business and Social Science, 1(2), 193-203.

Anderson, R. C., \& Reeb, D. M. (2003). Founding-family ownership and firm performance: Evidence from the 
S\&P 500. Journal of Finance, 58(3), 1301-1328. http://dx.doi.org/10.1111/1540-6261.00567

Andres, C. (2008). Large shareholders and firm performance-An empirical examination of founding-family ownership. Journal of Corporate Finance, 14(4), 431-445. http://dx.doi.org/10.1016/j.jcorpfin.2008.05.003

Astrachan, J., \& Shanker, M. (2003). Family businesses' contribution to the U.S. economy: A closer look. Family Business Review, 16(3), 211-219.

Baron, R. M., \& Kenny, D. A. (1986). The moderator-mediator variable distinction in social psychological research: Conceptual, strategic, and statistical considerations. Journal of Personality and Social Psychology, 51(6), 1173. http://dx.doi.org/10.1037/0022-3514.51.6.1173

Barontini, R., \& Caprio, L. (2006). The Effect of Family Control on Firm Value and Performance: Evidence from Continental Europe. European Financial Management, 12(5), 689-723. http://dx.doi.org/10.1111/j.1468036X.2006.00273.X

Barth, E., Gulbrandsen, T., \& Schone, P. (2005). Family ownership and productivity: The role of owner-management. Journal of Corporate Finance, 11(1-2), 107-127. http://dx.doi.org/10.1016/j.jcorpfin. 2004.02.001

Beiner, S., Drobetz, W., Schmid, M. M., \& Zimmermann, H. (2006). An Integrated Framework of Corporate Governance and Firm Valuation. European Financial Management, 12(2), 249-283. http://dx.doi.org/10. 1111/j.1354-7798.2006.00318.x

Ben-Amar, W., \& Andre, P. (2006). Separation of ownership from control and acquiring firm performance: The case of family ownership in Canada. Journal of Business Finance \& Accounting, 33(3-4), 517-543. http://dx.doi.org/10.1111/j.1468-5957.2006.00613.x

Berle, A. A., \& Means, G. C. (1932). The modern corporation and private property. Transaction Pub.

Block, J. (2010). Family Management, Family Ownership, and Downsizing: Evidence From S\&P 500 Firms. Family Business Review, 23(2), 109-130. http://dx.doi.org/10.1177/0894486509360520

Bocatto, E., Gispert, C., \& Rialp, J. (2010). Family-owned business succession: The influence of pre-performance in the nomination of family and nonfamily members: Evidence from Spanish firms. Journal of Small Business Management, 48(4), 497-523. http://dx.doi.org/10.1111/j.1540-627X.2010.00306. $\mathrm{x}$

Braumoeller, B. F. (2004). Hypothesis Testing and Multiplicative Interaction Terms. International Organization, 58(04), 807-820. http://dx.doi.org/10.1017/S0020818304040251

Burkart, M., Panunzi, F., \& Shleifer, A. (2003). Family firms. The Journal of Finance, 58(5), 2167. http://dx.doi.org/10.1111/1540-6261.00601

Chua, J. H., Chrisman, J. J., \& Sharma, P. (2003). Succession and Nonsuccession Concerns of Family Firms and Agency Relationship with Nonfamily Managers. Family Business Review, 16(2), 89-107. http://dx.doi.org/ $10.1111 / \mathrm{j} .1741-6248.2003 .00089 . \mathrm{x}$

Claessens, S., \& Djankov, S. (1999). Ownership Concentration and Corporate Performance in the Czech Republic. Journal of Comparative Economics, 27(3), 498-513. http://dx.doi.org/10.1006/jcec.1999.1598

Claessens, S., Djankov, S., \& Lang, L. H. P. (2000). The separation of ownership and control in East Asian Corporations. Journal of Financial Economics, 58(1-2), 81-112. http://dx.doi.org/10.1016/S0304-405X (00)00067-2

Collins, L., \& O'Regan, N. (2011). Editorial: The evolving field of family business. Journal of Family Business Management, 1(1), 5. http://dx.doi.org/10.1108/20436231111122245

Corbetta, G., \& Salvato, C. (2004). Self-Serving or Self-Actualizing? Models of Man and Agency Costs in Different Types of Family Firms: A Commentary on "Comparing the Agency Costs of Family and Non-Family Firms: Conceptual Issues and Exploratory Evidence". Entrepreneurship Theory and Practice, 28(4), 355. http://dx.doi.org/10.1111/j.1540-6520.2004.00050.x

Dalton, D. R., Daily, C. M., Ellstrand, A. E., \& Johnson, J. L. (1998). Meta-analytic reviews of board composition, leadership structure, and financial performance. Strategic Management Journal, 19(3), 269-290. http://dx.doi.org/10.1002/(SICI)1097-0266(199803)19:3<269::AID-SMJ950>3.0.CO;2-K

Davis, J. H., Schoorman, F. D., \& Donaldson, L. (1997). Toward a stewardship theory of management. Academy of Management. The Academy of Management Review, 22(1), 20-47. 
Dawson, J. (2013). Moderation in Management Research: What, Why, When, and How. Journal of Business and Psychology, 1-19.

Demsetz, H., \& Lehn, K. (1985). The Structure of Corporate Ownership: Causes and Consequences. Journal of Political Economy, 93(6), 1155-1177. http://dx.doi.org/10.1086/261354

Demsetz, H., \& Villalonga, B. (2001). Ownership structure and corporate performance. Journal of Corporate Finance, 7(3), 209-233. http://dx.doi.org/10.1016/S0929-1199(01)00020-7

Faccio, M., Lang, L. H. P., \& Young, L. (2001). Dividends and Expropriation. The American Economic Review, 91(1), 54-78. http://dx.doi.org/10.1257/aer.91.1.54

Fairchild, A. J., \& McQuillin, S. D. (2010). Evaluating mediation and moderation effects in school psychology: A presentation of methods and review of current practice. Journal of School Psychology, 48, 53-84. http://dx.doi.org/10.1016/j.jsp.2009.09.001

Filatotchev, I., Lien, Y. C., \& Piesse, J. (2005). Corporate Governance and Performance in Publicly Listed, Family-Controlled Firms: Evidence from Taiwan. Asia Pacific Journal of Management, 22(3), 257-283. http://dx.doi.org/10.1007/s10490-005-3569-2

Gallo, M., Tàpies, J., \& Cappuyns, K. (2004). Comparison of Family and Nonfamily Business: Financial Logic and Personal Preferences. Family Business Review, 17(4), 303. http://dx.doi.org/10.1111/j.1741-6248.2004. 00020.x

Hair, J. F., Black, W. C., Babin, B. J., \& Anderson, R. E. (2010). Multivariate Data Analysis (7th ed.). Prentice Hall.

Her, M. M., \& Williams, T. G. E. (2002). Founders Versus Descendants: Evidence Of The Taiwanese Publicly Traded Firms. International Business \& Economic Research Journal, 1(7).

Isakov, D., \& Weisskopf, J. P. (2009). Family Ownership, Multiple Blockholders and Firm Performance. SSRN eLibrary. http://dx.doi.org/10.2139/ssrn.1484574

Jaccard, J., \& Turrisi, R. (2003). Interaction Effects in Multiple Regression (2nd ed.). Thousand Oaks, California: SAGE Publications, Inc.

Jensen, M. C., \& Meckling, W. H. (1976). Theory of the Firm: Managerial Behavior, Agency Costs and Ownership Structure. Journal of Financial Economics, 3(4), 305-360. http://dx.doi.org/10.1016/0304-405X (76)90026-X

Jiang, Y., \& Peng, M. (2011). Are family ownership and control in large firms good, bad, or irrelevant? Asia Pacific Journal of Management, 28(1), 15-39. http://dx.doi.org/10.1007/s10490-010-9228-2

Kowalewski, O., Talavera, O., \& Stetsyuk, I. (2010). Influence of Family Involvement in Management and Ownership on Firm Performance: Evidence From Poland. Family Business Review, 23(1), 45-59. http://dx.doi.org/10.1177/0894486509355803

La Porta, R., Lopez-de-Silanes, F., \& Shleifer, A. (1999). Corporate ownership around the world. Journal of Finance, 54(2), 471-517. http://dx.doi.org/10.1111/0022-1082.00115

Lee, J. (2006). Family firm performance: Further evidence. Family Business Review, 19(2), 103-114. http://dx.doi.org/10.1111/j.1741-6248.2006.00060.x

Majumdar, S., \& Varadarajan, D. (2012). Family Ownership and Firm Performance in the United Arab Emirates. Paper presented at the International Conference on Excellence in Business. Retrieved from http://www.sharjah.ac.ae/en/about/agc/conferences/iceb/documents/papers/acc2.pdf

Martinez, J. I., Stohr, B. S., \& Quiroga, B. F. (2007). Family ownership and firm performance: Evidence from public companies in Chile. Family Business Review, 20(2), 83-94. http://dx.doi.org/10.1111/j.1741-6248. 2007.00087.x

Maury, B. (2006). Family ownership and firm performance: Empirical evidence from Western European corporations. Journal of Corporate Finance, 12(2), 321-341. http://dx.doi.org/10.1016/j.jcorpfin.2005. 02.002

Maury, B., \& Pajuste, A. (2005). Multiple large shareholders and firm value. Journal of Banking \& Finance, 29(7), 1813-1834. http://dx.doi.org/10.1016/j.jbankfin.2004.07.002

Mazzi, C. (2011). Family business and financial performance: Current state of knowledge and future research challenges. Journal of Family Business Strategy, 2(3), 166-181. http://dx.doi.org/10.1016/j.jfbs.2011.07.001 
McConaughy, D. L., \& Phillips, G. M. (1999). Founders versus Descendants: The Profitability, Efficiency, Growth Characteristics and Financing in Large, Public, Founding-Family-Controlled Firms. Family Business Review, 12(2), 123-131. http://dx.doi.org/10.1111/j.1741-6248.1999.00123.x

Miller, D., Le Breton-Miller, I., Lester, R. H., \& Cannella, A. A. (2007). Are family firms really superior performers? Journal of Corporate Finance, 13(5), 829-858. http://dx.doi.org/10.1016/j.jcorpfin.2007. 03.004

Morck, R., Shleifer, A., \& Vishny, R. W. (1988). Management Ownership and Market Valuation: An Empirical Analysis. Journal of Financial Economics, 20(1/2), 293. http://dx.doi.org/10.1016/0304-405X(88)90048-7

Mustakallio, M. A. (2002). Contractual and relational governance in family firms: Effects on strategic decision-making quality and firm performance. Unpublished $\mathrm{PhD}$ Dissertation, Helsinki University of Technology.

O'Boyle, E. H., Pollack, J. M., \& Rutherford, M. W. (2012). Exploring the relation between family involvement and firms' financial performance: A meta-analysis of main and moderator effects. Journal of Business Venturing, 21(1), 1-18. http://dx.doi.org/10.1016/j.jbusvent.2011.09.002

Perez-Gonzalez, F. (2006). Inherited control and firm performance. American Economic Review, 96(5), 1559-1588. http://dx.doi.org/10.1257/aer.96.5.1559

Ramachandran, K., \& Jha, R. (2007). Relevance of Agency and Stewardship Arguments in Family Business Context. Unpublished Working Paper.

Rutherford, M. W., Kuratko, D. F., \& Holt, D. T. (2008). The family business theory jungle: Competing theories on "Familiness" and performance. Entrepreneurship Theory and Practice, 32, 1089-1109. http://dx.doi.org/10.1111/j.1540-6520.2008.00275.x

Sacristan-Navarro, M., Gomez-Anson, S., \& Cabeza-Garcia, L. (2011). Family Ownership and Control, the Presence of Other Large Shareholders, and Firm Performance: Further Evidence. Family Business Review, 24(1), 71-93. http://dx.doi.org/10.1177/0894486510396705

Saito, T. (2008). Family firms and firm performance: Evidence from Japan. Journal of the Japanese and International Economies, 22(4), 620-646. http://dx.doi.org/10.1016/j.jjie.2008.06.001

Schulze, W. S., Lubatkin, M. H., Dino, R. N., \& Buchholtz, A. K. (2001). Agency Relationships in Family Firms: Theory and Evidence. Organization Science, 12(2), 99-116. http://dx.doi.org/10.1287/orsc.12.2.99.10114

Sciascia, S., \& Mazzola, P. (2008). Family Involvement in Ownership and Management: Exploring Nonlinear Effects on Performance. Family Business Review, 21(4), 331-345. http://dx.doi.org/10.1177/089448650 80210040105

Sciascia, S., Mazzola, P., Astrachan, J., \& Pieper, T. (2012). The role of family ownership in international entrepreneurship: Exploring nonlinear effects. Small Business Economics, 38(1), 15-31. http://dx.doi.org/10. 1007/s11187-010-9264-9

Seifert, B., Gonenc, H., \& Wright, J. (2005). The international evidence on performance and equity ownership by insiders, blockholders, and institutions. Journal of Multinational Financial Management, 15(2), 171-191. http://dx.doi.org/10.1016/j.mulfin.2004.08.003

Smith, B. F., \& Amoako-Adu, B. (1999). Management succession and financial performance of family controlled firms. Journal of Corporate Finance, 5(4), 341-368. http://dx.doi.org/10.1016/S0929-1199(99)00010-3

Sonfield, M. C., \& Lussier, R. N. (2004). First-, Second-, and Third-Generation Family Firms: A Comparison. Family Business Review, 17(3), 189-202. http://dx.doi.org/10.1111/j.1741-6248.2004.00013.x

Villalonga, B., \& Amit, R. (2006). How do family ownership, control and management affect firm value? Journal of Financial Economics, 80(2), 385-417. http://dx.doi.org/10.1016/j.jfineco.2004.12.005

Walsh, G. (2007). Family Business Succession: Managing the All-Important Family Component. Retrieved from http://www.kpmg.com/ca/en/services/kpmg-enterprise/centre-for-family-business/documents/3468_successi on.pdf

Wang, C. (2005). Ownership and operating performance of Chinese IPOs. Journal of Banking \& Finance, 29(7), 1835-1856. http://dx.doi.org/10.1016/j.jbankfin.2004.07.003

Ward, J. L. (1987). Keeping The Family Business Healthy. San Francisco: Jossey-Bass.

Westhead, P., \& Howorth, C. (2006). Ownership and management issues associated with family firm 
performance and company objectives. Family Business Review, 19(4), 301-316. http://dx.doi.org/10.1111/j. 1741-6248.2006.00077.x

Yeh, Y. H. (2005). Do Controlling Shareholders Enhance Corporate Value? Corporate Governance: An International Review, 13(2), 313. http://dx.doi.org/10.1111/j.1467-8683.2005.00425.x

Zahra, S. A. (2005). Entrepreneurial Risk Taking in Family Firms. Family Business Review, 18(1), 23-40. http://dx.doi.org/10.1111/j.1741-6248.2005.00028.x

Zahra, S. A., \& Sharma, P. (2004). Family business research: A strategic reflection. Family Business Review, 17(4), 331-346. http://dx.doi.org/10.1111/j.1741-6248.2004.00022.x

\section{Copyrights}

Copyright for this article is retained by the author(s), with first publication rights granted to the journal.

This is an open-access article distributed under the terms and conditions of the Creative Commons Attribution license (http://creativecommons.org/licenses/by/3.0/). 